\title{
PENDIDIKAN BUDI PAKERTI ANAK USIA DINI MELALUI FILM ANIMASI BERTEMA BUDAYA DAN AGAMA DI SDN 5 PADANGSAMBIAN
}

\author{
A.A. K. O. Sudana ${ }^{1}$, N.K.A. Wirdiani ${ }^{2}$, G.A.A. Putri ${ }^{3}$, dan N.K.D. Rusjayanthi ${ }^{4}$
}

\begin{abstract}
ABSTRAK
Pendidikan budi pekerti yang merupakan cikal bakal penuntun harmoni dalam kehidupan, harus dilakukan sejak usia dini agar nilai-nilai kemanusiaan yang terkandung didalamnya benar-benar menjadi bagian dalam kehidupan seseorang. Penanaman budi pekerti pada anak harus dilakukan sedini mungkin, mengingat masamasa anak di usia dini mudah merekam setiap informasi yang baru dalam otaknya. Kemajuan teknologi komputer, multimedia, internet dan smartphone memberi peluang untuk mengajarkan pendidikan budi pekerti kepada anak usia dini secara interaktif dan menarik, terutama melalui film animasi, game, video pembelajaran dengan topik cerita budaya dan agama. Melalui pelaksanaan kegiatan pengabdian pada masyarakat ini diusulkan sebagai rintisan wadah sosialisasi hasil karya di kampus terutama terkait dengan karya bidang teknologi informasi bisa benar-benar diketahui dan bermanfaat untuk masyarakat luas.

Kelurahan Padangsambian merupakan salah satu daerah yang perkembangan demografi kependudukannya sangat bervariasi dan dinamis di Kota Denpasar. Hal ini mempengaruhi model prilaku kehidupan masyarakat termasuk budi pakerti anak. Rintisan awal acara pengabdian pada masyarakat ini dilakukan di SD Negeri 5 Padangsambian dengan dengan peserta didik dari warga asli dengan kondisi ekonomi relatif kurang mampu, serta sebagian dari warga pendatang yang kondisi relatif mapan, dianggap cukup mewakili kondisi secara umum variasi model siswa Sekolah Dasar di Wilayah Padangsambian.
\end{abstract}

Kata kunci : teknologi informasi, pendidikan budi pekerti, anak usia dini, film animasi.

\begin{abstract}
Ethical education which is the beginning to guiding harmony in life, must be done from an early age so that the human values contained therein truly become a part of one's life. Character and ethic education in children must be done as early as possible, bearing in mind the childhood at an early age is easy to record any new information in his brain. Advances in computer technology, multimedia, internet and smartphones provide opportunities to teach character education to children in an interactive and interesting way, especially through animated films, games, learning videos on the topic of cultural and religious stories. Through the implementation of community service activities, it is proposed as a pioneering platform for the dissemination of works on campus especially related to IT that can be truly known and beneficial to the wider community. Padangsambian is one of the areas where the demographic development of the population is very varied and dynamic in the City of Denpasar. This affects the behavior model of community life including the mind and child. The initial pioneering program of community service was conducted at SD Negeri 5 Padangsambian with students from indigenous people with relatively poor economic conditions, as well as some of the migrants who were relatively well-established, considered to be sufficiently representative of the general condition of variations in the model of elementary school students in the region of Padangsambian.
\end{abstract}

Keywords: information technology, character education, early childhood, animated films

\footnotetext{
${ }^{1}$ Program Studi Teknologi Informasi; agungokas@unud.ac.id.

${ }^{2}$ Program Studi Teknologi Informasi; ayuwirdiani@unud.ac.id

${ }^{3}$ Program Studi Teknologi Informasi; agung.ayuputri@unud.ac.id

${ }^{4}$ Program Studi Teknologi Informasi; $\underline{\text { dwi.rusjayanthi@unud.ac.id }}$
} 


\section{PENDAHULUAN}

Banyak penelitian dan hasil karya berupa Sistem Aplikasi yang telah dihasilkan oleh Dosen dan Mahasiswa Jurusan Teknologi Informasi, Fakultas Teknik, Universitas Udayana. Sistem-sistem Aplikasi tersebut merupakan penerapan teknologi informasi pada berbagai bidang seperti pendidikan, kesehatan, industri, hukum, pertanian, sosial budaya dan lain sebagainya. Khusus implementasi TI pada bidang Budaya Bali dan Agama Hindu juga telah banyak yang berhasil dihasilkan. Contoh dari hasil karya ini adalah Animasi Tata Cara Persembahyangan, Sistem Informasi Bebantenan dan Ulam Bebantenan, Sistem Informasi Upacara Yadnya, Sistem Informasi Ulam Bebantenan, Sistem Pembelajaran Pembuatan Banten berbasis Animasi 3 Dimensi, Sistem Informasi Ala-ayuning Dewasa, Sistem Peramalan Jodoh, Sistem Informasi Tanaman Obat Tradisional, Sistem Pengenalan Aksara Bali, Sistem Kamus Bali-Indonesia, beberapa film animasi yang mengambil cerita Rakyat Bali sebagai tema, dan beberapa sistem lainnya[Oka Sudana, 2011].

Sistem-sistem yang telah dibuat ini hanya diketahui oleh kalangan internal kampus dan dipublikasikan melalui media akademik berupa jurnal yang tidak langsung menyentuh kepada masyarakat yang semestinya bisa memanfaatkan hasil karya tersebut secara maksimal. Melalui pelaksanaan kegiatan pengabdian pada masyarakat ini diusulkan sebagai rintisan wadah sosialisasi hasil karya yang dihasilkan di kampus terutama terkait dengan karya bidang teknologi informasi bisa benar-benar diketahui dan dimanfaatkan oleh masyarakat luas, sehingga tujuan ikut berperan nyata dalam pelestarian budaya bangsa bisa terwujud.

Sembahyang atau sering juga disebut muspa kramaning sembah merupakan jalan dan salah satu cara untuk memuja Tuhan (Ida Sang Hyang Widhi Wasa). Salah satu hakekat dalam ajaran agama adalah sembahyang. Sembahyang dalam kehidupan sehari-hari berarti muspa, mebakti atau maturan. Banyak macam sembahyang ditinjau dari kapan dilakukan, dengan cara apa, dengan sarana apa, dimana serta siapa yang melakukan. Kemantapan hati dalam melakukan sembahyang, membantu komunikasi yang lancar dan pemuasan rohani. Kemantapan rohani akan diperoleh apabila tata cara persembahyangan yang dilakukan sudah benar dan sesuai serta makna yang terkandung dalam setiap langkah dan cara telah dipahami.Pemahaman mengenai tata cara persembahyangan tidak hanya bertujuan untuk menambah pengetahuan semata, tetapi dapat pula berpengaruh terhadap usaha meningkatkan moral generasi muda. Pemahaman tata cara persembahyangan perlu ditanamkan sejak dini tidak hanya di lingkungan keluarga juga dari lingkungan sekolah.

Banyak hal yang dapat diupayakan untuk mengatasi terjadinya hal seperti di atas dan perlu dipikirkan suatu cara yang dapat membantu pemahaman mengenai cara meningkatkan budi pekerti dan moral generasi muda, sehingga akan memudahkan masyarakat dalam mengetahui dan mempelajarinya. Salah satu cara yang dapat ditempuh adalah dengan dukungan teknologi informasi yaitu dengan telah adanya suatu aplikasi tata cara persembahyangan yang berbasis mutimedia khususnya dukungan video dan animasi 3 dimensi dan juga kartun animasi yang mengajarkan generasi muda untuk selalu berbuat baik. Ada beberapa sistem yang telah dihasilkan, akan tetapi belum banyak dimanfaatkan dan dikenal oleh masyarakat luas. Memasyarakatkan dan menginformasikan hal ini terutama kepada kalangan generasi muda yang sudah banyak memiliki perangkat TI sudah merupakan tuntutan, sehingga hasil karya yang sebenarnya sangat bermanfaat tersebut tidak hanya terpendam di dunia kampus tanpa pernah dimanfaatkan.

Kelurahan Padangsambian merupakan salah satu daerah yang perkembangan demografi kependudukannya sangat bervariasi dan dinamis di Wilayah Kota Denpasar. Hal ini turut mempengaruhi model prilaku kehidupan masyarakat termasuk budi pakerti anak-anak. Rintisan awal acara pengabdian pada masyarakat ini dilakukan pada sekolah dasar di Padangsambian. SD Ngeri 5 Padangsambian dengan dengan peserta didik dari warga asli dengan kondisi ekonomi 
relatif kurang mampu dianggap cukup mewakili kondisi secara umum model siswa sekolah dasar di Wilayah Padangsambian. SD Negeri 5 Padangsambian yang beralamat di Jalan Tangkuban Perahu, Padangsambian memiliki sekitar 700 orang siswa, mulai dari Kelas 1 sampai Kelas 6, yang mana pada setiap angkatan terdiri dari 4 kelas. Guru pada SD ini terdiri dari 23 orang guru. Kurikulum pada SD ini juga sudah mengajarkan tentang budi pekerti serta budaya dan agama Anak-anak mudah terpengaruh oleh apa yang mereka lihat salah satunya adalah dari tayangan televisi dan games yang kurang mendidik sehingga itu hal itu sering kali diterapkan dalam keseharian anakanak tersebut.

Penggunaan teknologi informasi sudah sangat familiar di kalangan anak-anak, bahkan anak playgroup pun sudah mahir menggunakan smartphone dan internet. Apabila penggunaan teknologi ini tidak diawasi anak-anak akan cenderung menggunakan aplikasi (game) dan konten yang terkesan tidak medidik atau mengarah ke hal-hal yang negatif. Media teknologi informasi yang mengajarkan budi pekerti kepada anak secara interaktif dan video animasi yang mendidik dapat dengan mudah diserap oleh anak-anak sehingga diharapkan dapat menuntun anak-anak menjadi sopan dan taat aturan atau memliki budi pakerti yang baik.

\section{METODE PELAKSANAAN}

\subsection{Tujuan Kegiatan}

Adapun tujuan dari kegiatan pengabdian ini adalah:

1. Memberikan sumbangsih nyata pada masyarakat dalam Bidang Penanaman Budi Pakerti kepada anak usia dini yang pada saat ini dirasakan semakin terkikis dan semakin jauh dari budaya adiluhung bangsa, melalui pemanfaatan teknologi informasi.

2. Memberikan pengetahuan kepada anak usia dini dari Masyarakat Bali yang melalui sekolah taman kanak-kanak mengenai pemanfaatan teknologi informasi pada bidang budaya. Penyajian dengan teknologi animasi dan multimedia diharapkan mampu lebih menarik perhatian anak usia dini yang pada dasarnya sangat senang melihat film-film atau gambar animasi.

3. Sedini mungkin memberikan pengetahuan kepada anak-anak untuk membiasakan diri memanfaatkan produk teknologi modern khususnya teknologi informasi untuk hal-hal yang bersifat positif dalam kehidupan sehari-hari.

4. Memperkenalkan karya-karya yang civitas akademika kampus kepada masyarakat luas, sehingga diketahui dan bisa dimanfaatkan, tidak hanya tersimpan dan dikenal dikalangan internal kampus saja.

\subsection{Khalayak Strategis}

Sasaran strategis yang bisa dilibatkan dalam pelaksanaan pengabdian pada masyarakat ini adalah sebagai berikut:

1. Kepala sekolah berperan dalam mengijinkan, medukung dan menyediakan tempat pelaksanaan program. Membuat kebijakan untuk mewajibkan guru-guru ikut membantu dalam pelaksaan kegiatan, serta kebijakan keberlanjutan penggunaan aplikasi ditahun-tahun berikutnya.

2. Guru-guru SD berperan dalam menyiapkan siswa untuk mengikuti kegiatan sosialisasi, serta membantu pelaksanaan sosialisasi. Mengingatkan dan memberi afirmasi kepada siswa terkait aplikasi yang telah disosialisasikan, untuk lebih mempermudah siswa memahami nilai yang terkandung dari sistem atau aplikasi yang disosialisasikan. Mendampingi siswa untuk mempraktekkan metode-metode yang ditampilkan pada aplikasi tatacara persembahyangan.

3. Siswa SD berperan sebagai audien sosialisasi dan menggunakan dirumah aplikasi yang telah disosialisasikan. 


\subsection{Persoalan Prioritas Mitra}

Persoalan prioritas yang dihadapi mitra adalah semakin terkikisnya budi pekerti generasi muda khususnya anak-anak usia dini yang terpengaruh oleh tayangan televisi dan pemanfaaatan teknologi informasi yang kurang mendidik. Ini dapat terlihat dari keseharian mereka yang kecenderungan egois, suka memukul dan kurang sopan kepada orang yang lebih tua. Metode pembelajaran yang belum banyak memanfaatkan teknologi informasi khususnya multimedia yang lebih menyenangkan juga belum banyak digunakan, sehingga pola pembelajaran cenderung konvensional dan kurang menarik.

\subsection{Metode Pendekatan yang Ditawarkan}

Metode pendekatan yang ditawarkan untuk menyelesaikan persoalan ini adalah dengan metode pembelajaran alternatif memanfaatkan penggunaan teknologi informasi khususnya multimedia dan internet berupa aplikasi pembelajaran tatacara persembahyangan, film animasi, dan games dengan topik bidang budaya dan agama. Aplikasi-aplikasi tersebut berisi animasi film yang menarik sehingga diharapkan anak didik usuia dini lebih tertarik untuk belajar dan lebih mudah untuk memahami apa yang dilihat pada animasi tersebut.

\section{HASIL DAN PEMBAHASAN}

\subsection{Langkah-langkah Pengabdian}

Pelaksanaan pengabdian pada masyarakat ini dibagi menjadi beberapa tahapan pelaksanaan, yang mana secara garis besarnya terdiri dari tahap persiapan sistem serta sosialisasi dan implementasi kepada mitra, dengan rincian sebagai berikut:

1. Pengumpulan data dan studi literatur yang berhubungan dengan pendidikan budi pekerti berbasis Multimedia dan Animasi 3D;

2. Penyiapan materi berupa kompilasi aplikasi yang akan disosialisasikan serta memperbanyak CD Aplikasi;

3. Sosialisasi ke guru mengenai pemanfaatan Teknologi Informasi tentang Animasi Pembelajaran dengan topik bidang budaya dan agama;

4. Sosialisasi ke siswa mengenai pemanfaatan Teknologi Informasi tentang Animasi Pembelajaran dengan topik bidang budaya dan agama. Sosialisasi video animasi kartun budi pekerti;

5. Mengingatkan kembali dan afirmasi dari guru ke siswa dalam kegiatan belajar mengajar;

6. Pembagian CD aplikasi ke siswa;

7. Sosialisasi ke orang tua siswa melalui surat untuk pemanfaatan CD aplikasi dan mendampingi mendampingi siswa di rumah dalam keseharian terkait praktek cara persembahyangan dan diingatkan kembali oleh guru pada saat rapat orang tua siswa;

8. Tahap evaluasi pelaksanaan dan pelaporan.

\subsection{Produk yang Disosialisasikan}

Model produk yang ditransfer kepada kedua mitra adalah berupa bemberian CD Aplikasi Pembelajaran dan film animasi terkait Budaya dan Agama, yang mana diawali dengan sosialisasi dan demo aplikasi. Detail Produk yang ditansfer atau diberikan kepada mitra adalah sebagai berikut:

1. CD Multimedia dan Animasi Pembelajaran Tatacara Persembahyangan dalam Agama Hindu[Hadi Suadnyana, 2013], CD Multimedia Pembelajaran tata cara sembahyang dalam 
Agama Hindu ini berisi tentang video animasi dasar-dasar sikap sembahyang yang digunakan dalam keseharian Umat Hindu. Juga berisi tentang cerita Orang-orang Suci, dan Susila dalam keseharian[Wahyu, 2014];

2. Film Animasi berbasis Cerita Rakyat Bali dengan Judul "I BELOG" dan "TERJADINYA SELAT BALI"; Film animasi berjudul "I BELOG" diambil dari cerita Rakyat Bali yang cukup populer, sangat bagus dan sangat menarik jika ditonton oleh anak usia dini, yang mana mengandung tuntunan prilaku dan kehidupan sehari-hari untuk menghindari kebodohan[Jaya Kasunu, 2013].

3. Game-game berbasis budaya dan agama karya Mahasiswa Jurusan Teknologi Informasi, seperti Game Nanding Canang [Krisnandari, 2013] dan Game Ngelawar [Danni Krisnawan, 2014].

\subsection{Dokumentasi Acara Puncak Pengabdian}

Kegiatan Puncak Pengabdian diisi dengan Sosialisasi dan Pelatihan Pengenalan yang dilaksanakan pada Hari Sabtu, 20 Juli 2019. Berikut ini disajikan beberapa foto bukti kegiatan.

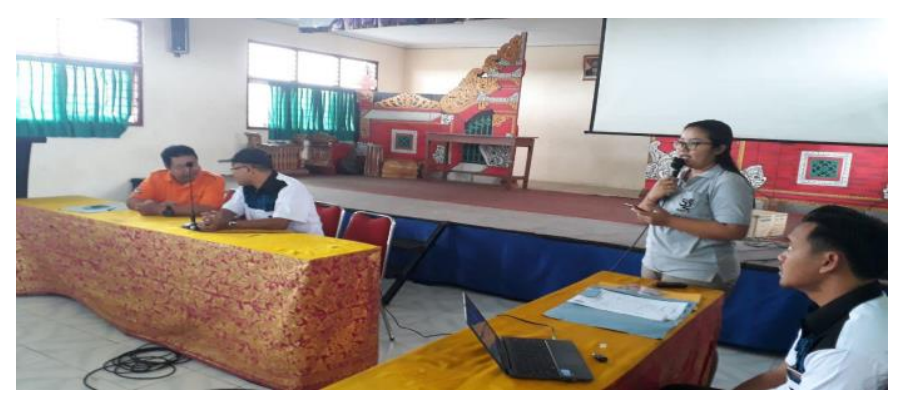

Gambar 3.1. Situasi acara pembukaan oleh Kepala Sekolah.

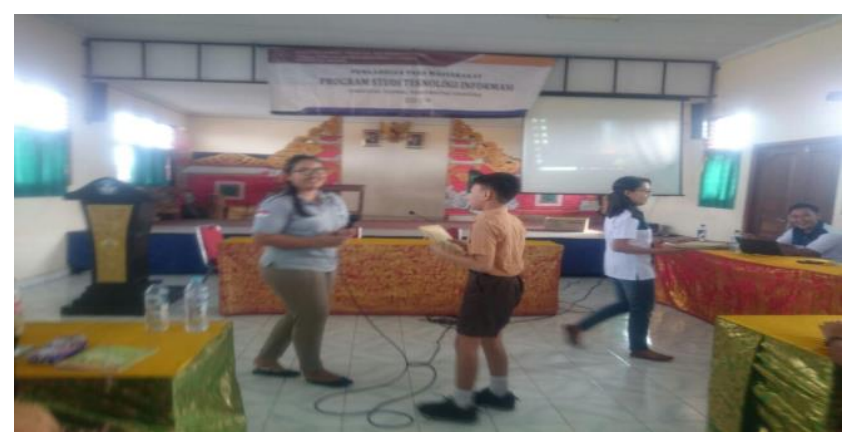

Gambar 3.2. Suasana Acara Pengabdian, interaksi dengan siswa dengan pemberian kuis.

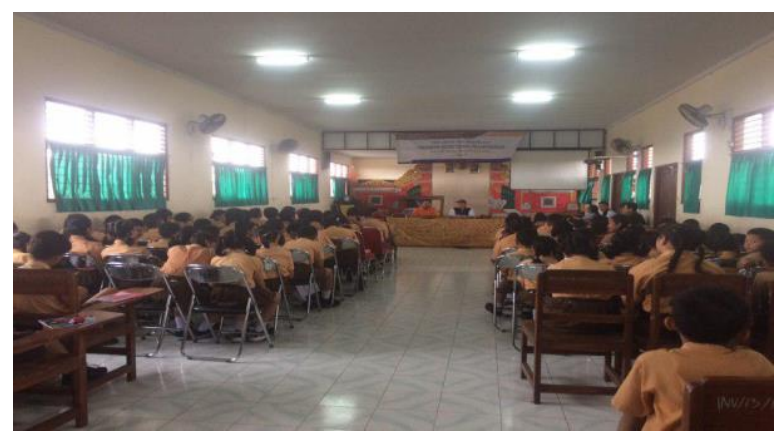


Gambar 3.3. Penjelasan kepada Siswa, Kepala Sekolah dan Guru-guru.

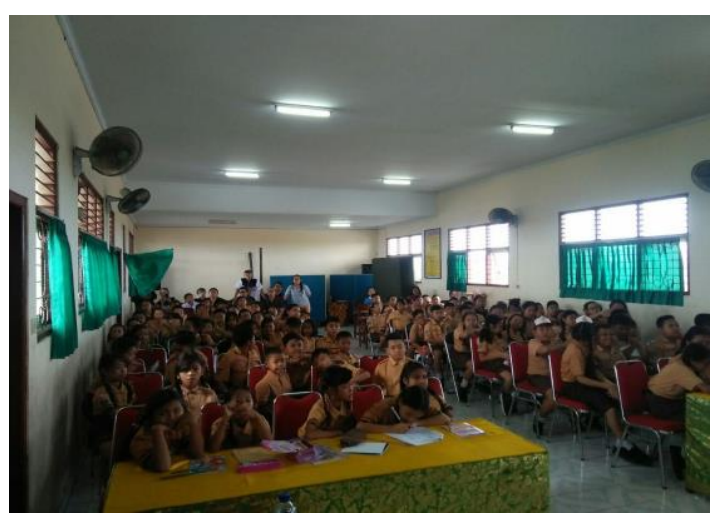

Gambar 3.4. Penjelasan kepada Siswa, Kepala Sekolah dan Guru-guru (2).

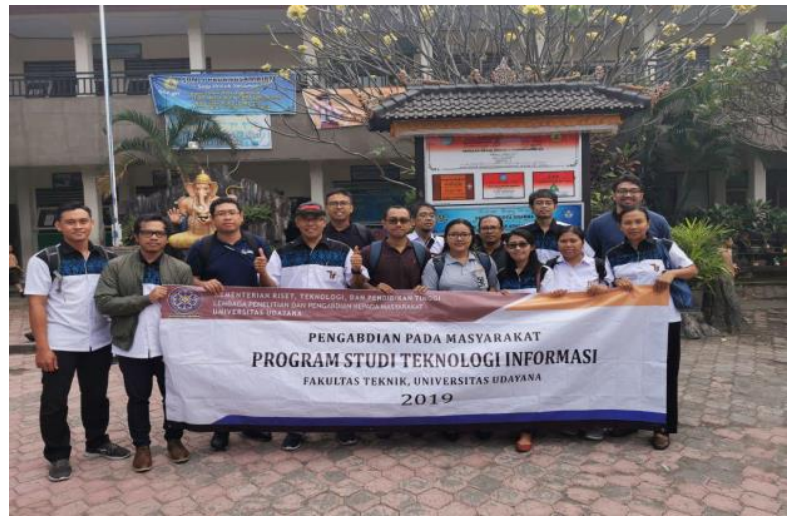

Gambar 3.5. Partisipasi Civitas Program Studi Teknologi Informasi, Unud.

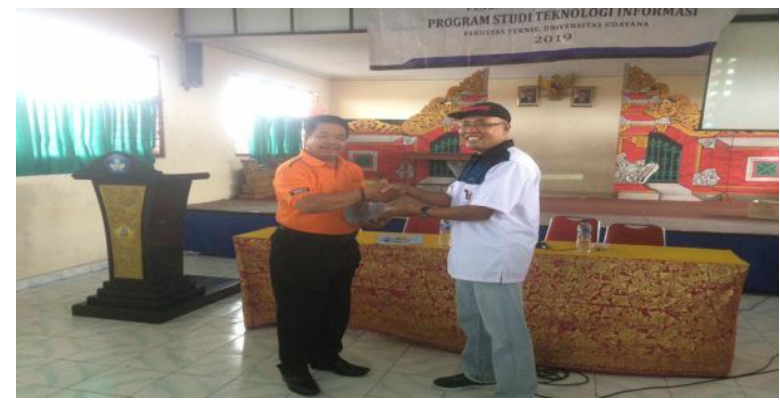

Gambar 3.6. Penyerahan Produk dari Ketua Tim Pengabdian kepada Kepala Sekolah.

\section{KESIMPULAN}

Adapun kesimpulan yang bisa didapatkan dari pengembangan aplikasi Pengenalan huruf dan angka berbasis smartphone ini adalah sebagai berikut:

1. Kemajuan teknologi informasi khususnya dalam bentuk multimedia, internet dan smartphone memberi peluang besar untuk mengajarkan pendidikan agama dan budi pekerti kepada anak usia dini dengan cara yang interaktif dan menarik, terutama melalui film animasi, game, video pembelajaran yang mengangkat topik cerita budaya dan agama. 
2. Melalui pelaksanaan kegiatan pengabdian pada masyarakat ini digunakan sebagai rintisan wadah sosialisasi hasil karya yang dihasilkan di kampus terutama terkait dengan karya bidang teknologi informasi bisa benar-benar diketahui dan bermanfaat untuk masyarakat luas, sehingga tujuan ikut berperan nyata dalam memajukan bangsa bisa terwujud.

3. Kelurahan Padangsambian merupakan salah satu daerah yang perkembangan demografi kependudukannya sangat bervariasi dan dinamis di Wilayah Kota Denpasar. Hal ini turut mempengaruhi model prilaku kehidupan masyarakat termasuk budi pakerti anak-anak. Rintisan awal acara pengabdian pada masyarakat ini dilakukan di SD Negeri 5 Padangsambian dengan dengan peserta didik dari warga asli dengan kondisi ekonomi relatif kurang mampu, serta sebagian dari warga pendatang yang kondisi relatif mapan, dianggap cukup mewakili kondisi secara umum variasi model siswa sekolah dasar di Wilayah Padangsambian.

4. Sistem telah diimplementasikan dan dimanfaatkan melalui acara Pengabdian pada Masyarakat untuk anak usia dini khususnya di SD Negeri 5 Padangsambian, Kelurahan Padangsambian, Denpasar yang acara puncaknya dirangkaikan dengan sosialisasi pemutaran film-film animasi bertemakan budaya dan agama.

\section{UCAPAN TERIMA KASIH}

Terimakasi kami ucapkan kepada Fakultas Teknik Universitas Udayana yang membiayai kegiatan pengabdian ini, Bapak Kepala Sekolah, Guru-guru dan Siswa SD Negeri 5 Padangsambian dan Civitas Program Studi Teknologi Informasi, Fakultas Teknik, Universitas Udayana.

\section{DAFTAR PUSTAKA}

Danni Krisnawan IB; Agung Cahyawan; Oka Sudana; 2014; Rancang Bangun Game Edukasi "Lawar Bali” pada Platform Android; Tugas Akhir pada Program Studi Teknologi Informasi, Universitas Udayana.

Hadi Suadnyana, Ketut; Piarsa, I Nyoman; Oka Sudana AAK.,;2013; Multimedia Interaktif sebagai Media Bantu Guru dalam Pembelajaran Agama Hindu; Tugas Akhir Jurusan Teknik Elektro, Universitas Udayana.

Jaya Kasunu; Oka Sudana AAK; 2013; Pembuatan File Animasi "I BELOG"; Tugas Akhir Jurusan Teknik Elektro, Universitas Udayana.

Krisnandari, Dian; Oka Sudana AAK; 2013; Rancang Bangun Game Edukasi Metanding Canang pada Android Mobile Platform; Skripsi Program Studi Teknologi Informasi Universitas Udayana, Bali.

Oka Sudana AAK; Kurnia Jayanti, Ida Ayu Gde; 2011; Implementasi Struktur Tree untuk Pemodelan Sistem Informasi Bebantenan On-line dalam Upacara Yadnya Agama Hindu; Proceding Snatika 2011, Malang.

Wahyu Kumara Putri IA; Oka Sudana AAK; Ika Marini; 2014; Aplikasi Game Edukasi Banten Pejati pada smartphone berbasis Android; Tugas Akhir pada Program Studi Teknologi Informasi, Universitas Udayana. 